\title{
High Concentration of C5a-Induced Mitochondria-Dependent Apoptosis in Murine Kidney Endothelial Cells
}

\author{
I-Jung Tsai ${ }^{1}{ }^{\mathbb{D}}$, Wei-Chou Lin ${ }^{2}$, Yao-Hsu Yang ${ }^{1}$, Yu-Lin Tseng ${ }^{1}$, Yen-Hung Lin ${ }^{3}{ }^{\mathbb{D}}$, \\ Chia-Hung Chou ${ }^{4, *}$ and Yong-Kwei Tsau ${ }^{1}$ \\ 1 Department of Pediatrics, National Taiwan University Hospital and National Taiwan University College \\ of Medicine, Taipei 100, Taiwan \\ 2 Department of Pathology, National Taiwan University Hospital and National Taiwan University College \\ of Medicine, Taipei 100, Taiwan \\ 3 Department of Internal Medicine, National Taiwan University Hospital and National Taiwan University \\ College of Medicine, Taipei 100, Taiwan \\ 4 Department of Obstetrics and Gynecology, National Taiwan University Hospital and National Taiwan \\ University College of Medicine, Taipei 100, Taiwan \\ * Correspondence: ch640124@yahoo.com.tw; Tel.: +886-2-2312-3456; Fax: +886-2-23147450
}

Received: 21 July 2019; Accepted: 9 September 2019; Published: 10 September 2019

\begin{abstract}
Patients with a relapse of idiopathic nephrotic syndrome have significantly increased levels of serum complement component $5 \mathrm{a}(\mathrm{C} 5 \mathrm{a})$, and proteinuria has been noted in mice treated with C5a via changes in permeability of kidney endothelial cells (KECs) in established animal models. However, the apoptosis of KECs treated with high concentrations of $\mathrm{C} 5 \mathrm{a}$ has also been observed. As mitochondrial damage is known to be important in cell apoptosis, the aim of this study was to examine the association between C5a-induced mouse KEC apoptosis and mitochondrial damage. Mouse KECs were isolated and treated with different concentrations of C5a. Cell viability assays showed that a high-concentration mouse recombinant protein $\mathrm{C} 5 \mathrm{a}(\mathrm{rmC5})$ treatment reduced mouse KEC growth. Cell cycle phase analysis, including apoptosis (sub-G1 phase) showed an increased percentage of the subG1 phase with a high-concentration rmC5a treatment. Cytochrome $c$ and caspase $3 / 9$ activities were significantly induced in the mouse KECs after a high-dose rmC5a ( $50 \mathrm{ng} / \mathrm{mL})$ treatment, and this was rescued by pretreatment with the C5a receptor (C5aR) inhibitor (W-54011) and $\mathrm{N}$-acetylcysteine (NAC). Reactive oxygen species (ROS) formation was detected in C5a-treated mouse KECs; however, W-54011 or NAC pretreatment inhibited high-dose rmC5a-induced ROS formation and also reduced cytochrome c release, apoptotic cell formation, and apoptotic DNA fragmentation. These factors determined the apoptosis of mouse KECs treated with high-dose C5a through C5aR and subsequently led to apoptosis via ROS regeneration and cytochrome $\mathrm{c}$ release. The results showed that high concentrations of C5a induced mouse KEC apoptosis via a C5aR/ROS/mitochondria-dependent pathway. These findings may shed light on the potential mechanism of glomerular sclerosis, a process in idiopathic nephrotic syndrome causing renal function impairment.
\end{abstract}

Keywords: kidney endothelial cell; apoptosis; ROS regeneration; mitochondria; C5a

\section{Introduction}

Serum complement component $5 \mathrm{a}$ (C5a) is a small soluble peptide fragment generated from complement cascade activation that regulates many inflammatory pathways, such as the degranulation of mast cells [1], neutrophil chemotaxis [2], and T lymphocyte infiltration [3]. In non-myeloid cells, 
C5a has been reported to cause renal injuries, such as renal transplantation allograft survival and renal ischemia-reperfusion injury [4-6].

In the glomerular filtration barrier (GFB), the key mechanism regulating the barrier between podocytes and glomerular endothelial cells is unclear. Patients with early diabetes, pre-eclampsia and a rare hereditary nephrotic syndrome may present with proteinuria without any structural changes in podocytes [7-9]. Some studies have reported that podocytes produce vascular endothelial growth factor (VEGF) and may influence the function and survival of adjacent endothelial cells [10]. In our previous study, we demonstrated C5a-induced proteinuria in murine nephrotic syndrome via a Rho-associated kinase (ROCK) pathway in glomerular endothelial cells [11].

In general, endothelial cells play an important role in inflammatory processes such as atherosclerosis and sepsis [12-15]. C5a and C3a are known to be anaphylatoxins, to promote pro-inflammatory conditions, and to induce cell apoptosis. C5a is the more potent stimulant and can cause chemotaxis and produce oxidative substances by phagocytic cells $[12,13,16]$. In addition, C5a receptors (C5aR and CD88) exist in both myeloid cells (e.g., monocytes, macrophages and polymononuclear cells) and endothelial cells [17-20].

Recently, we identified that high concentrations of C5a may induce cellular apoptosis in kidney endothelial cells (KECs). This high concentration of C5a caused cellular apoptosis through C5a/C5aR in mouse KECs via cytochrome $\mathrm{c}$ and caspase 3/9 activities, which were dependent on reactive oxygen species (ROS) formation; as such, this apoptosis was mitochondrial-dependent.

\section{Results}

\subsection{High-Dose C5a Treatment Reduced Mouse KEC Growth}

The growth inhibitory effect of C5a on mouse KECs was determined by an MTT assay under different concentrations of Mouse recombinant protein $\mathrm{C} 5 \mathrm{a}$ ( $\mathrm{rmC5}$ ) for three days. A high concentration $(50 \mathrm{ng} / \mathrm{mL})$ of rmC5a significantly reduced the relative viability of mouse KECs compared to the vehicle on day two and day three (Figure 1). These data suggested that a high dose of C5a reduced the growth of mouse KECs.

A

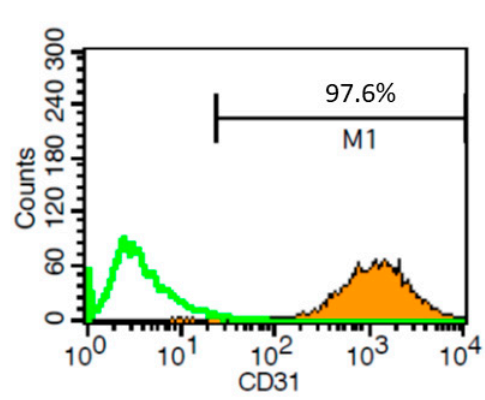

B

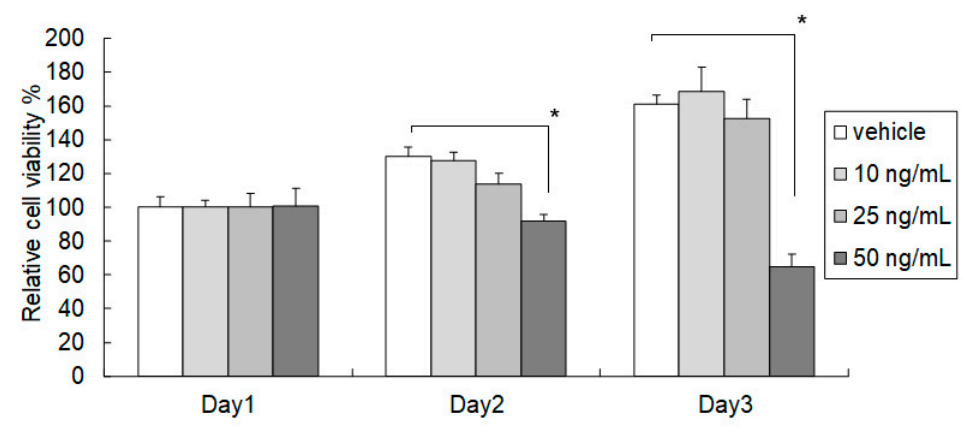

Figure 1. High-dose C5a treatment reduced mouse kidney endothelial cell (KEC) growth. (A) The ratio of CD31-positive cells were analyzed by flow cytometry using a FACScan and the Cell Quest software to quantify the CD31-positive cells. The white histograms were isotype controls, whereas the orange overlays were of CD31-positive cells. (B) Mouse KECs were treated with $0-50 \mathrm{ng} / \mathrm{mL}$ of Mouse recombinant protein $\mathrm{C} 5 \mathrm{a}$ ( $\mathrm{rmC5}$ ) for different periods of time. The cell viability was determined by an MTT assay. The data are presented as mean $\pm \mathrm{SD} .{ }^{*} p<0.05$.

\subsection{High-Dose C5a Treatment Induced Apoptosis of Mouse KECS}

Mouse KECs were treated with rmC5a for $48 \mathrm{~h}$, and the cell cycle phases including apoptosis (subG1 phase) were analyzed. The vehicle and $10 \mathrm{ng} / \mathrm{mL}$ of $\mathrm{rmC} 5$ a did not change the cell cycle phases or induce an apoptosis of the mouse KECs. However, $25 \mathrm{ng} / \mathrm{mL}$ of rmC5a slightly but significantly 
induced a sub-G1 peak ratio, and $50 \mathrm{ng} / \mathrm{mL}$ of rmC5a markedly induced a sub-G1 peak ratio, which represented an apoptosis of the mouse KECs (Figure 2A,B). The early and late stage apoptotic cells were determined by staining both with propidium iodine (PI) and Annexin V-FITC, and $50 \mathrm{ng} / \mathrm{mL}$ of rmC5a induced a significant increase of apoptotic percentage in mouse KECs (Figure 2C,D). The lactate dehydrogenase (LDH) assay showed no difference between different concentrations of rmC5a. These results indicated that a high dose of C5a could induce mouse KEC apoptosis.

A
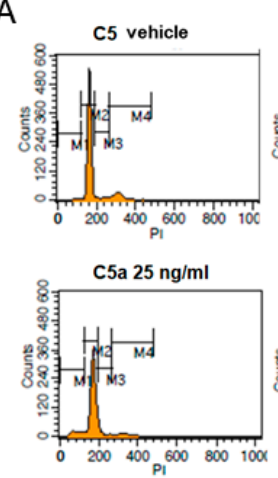

C
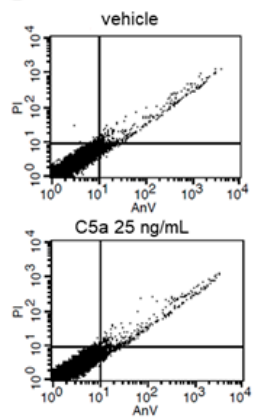
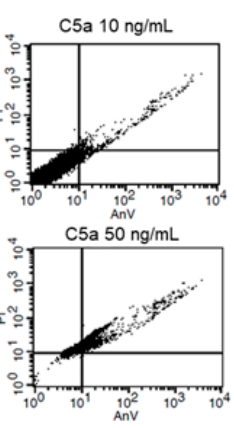

C5a $10 \mathrm{ng} / \mathrm{ml}$
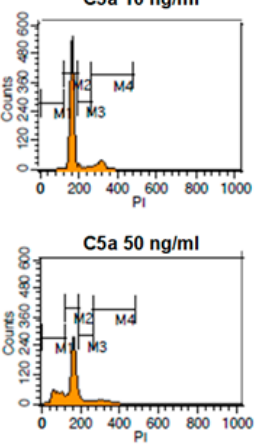

D
B

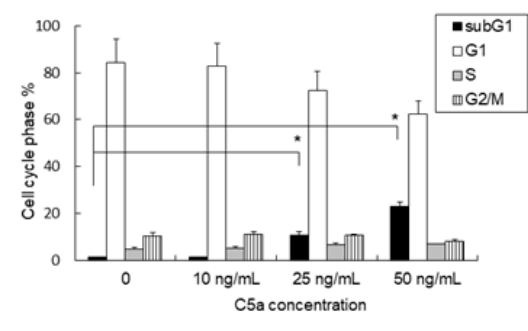

E
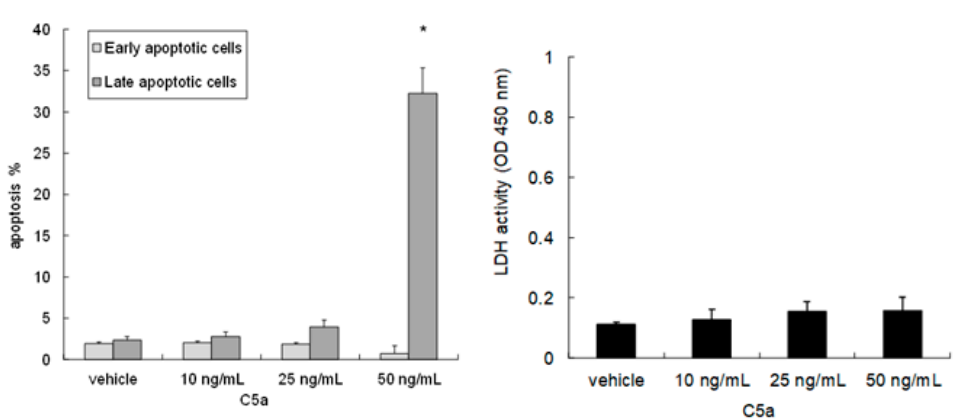

Figure 2. High-dose C5a treatment induced the apoptosis of mouse KECs. (A) Mouse KECs were treated with 0-50 ng/mL of rmC5a for $48 \mathrm{~h}$. The cell cycle phases including apoptosis (sub-G1 phase) were analyzed by PI staining and flow cytometry. (B) The data are represented as mean $\pm \mathrm{SD}$. ${ }^{*} p<0.05$. (C) Mouse KECs were treated with 0-50 ng/mL of rmC5a for $48 \mathrm{~h}$. The early and late stage apoptotic cells were determined by staining with both PI and annexin V-FITC as well as flow cytometry. (D) The quantitative data are represented as mean \pm SD. ${ }^{*} p<0.05$. (E) The culture supernatant was collected from mouse KECs treated with 0-50 ng/mL of rmC5a for $48 \mathrm{~h}$. Lactate dehydrogenase (LDH) activity of cell culture supernatant from each sample was measured by an LDH assay. The data are represented as the mean color intensity $(\mathrm{OD} 450 \mathrm{~nm}) \pm \mathrm{SD}$ of five independent analyses.

\subsection{High-Dose C5a Treatment Induced Cytochrome $c$ and Caspase 3/9 Activities through C5aR in Mouse KECs}

Apoptosis is associated with the activation of cytochrome $\mathrm{c}$ and caspase 3/9. To clarify the role of C5aR in apoptosis induced by C5a, mouse KECs were pretreated with the C5aR inhibitor W-54011 prior to $\mathrm{C} 5 \mathrm{a}$ treatment. The results revealed that $50 \mathrm{ng} / \mathrm{mL}$ of rmC5a significantly induced cytochrome c release (Figure 3A) and caspase 3/9 activity (Figure 3B) in mouse KECs, whereas pretreatment with the C5aR inhibitor significantly rescued these induction effects (Figure 3). These results demonstrated that a high dose of C5a induced apoptosis through C5aR on mouse KECs. 
A

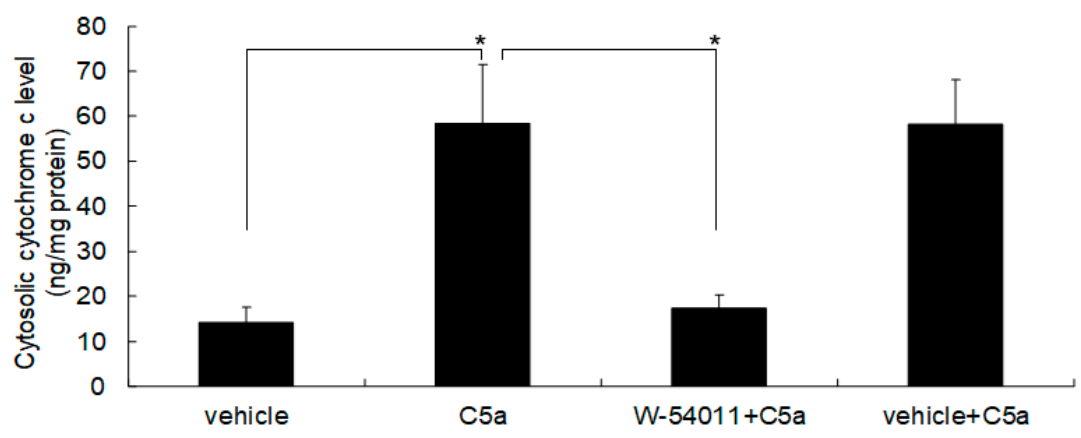

B

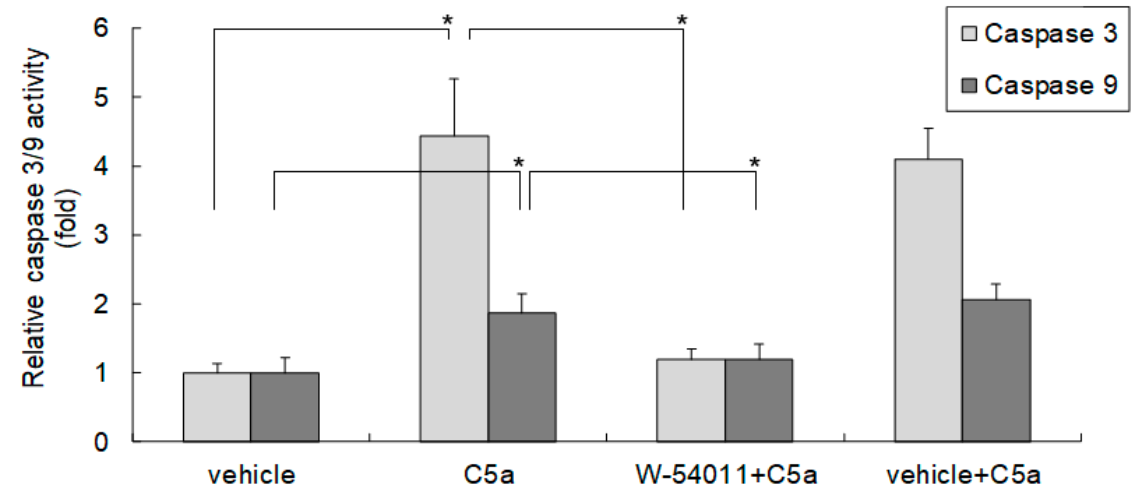

Figure 3. High-dose $\mathrm{C} 5$ a treatment induced cytochrome $\mathrm{c}$ and caspase $3 / 9$ activities through $\mathrm{C} 5 \mathrm{aR}$ in mouse KECs. Mouse KECs were pretreated with the C5aR inhibitor (W-54011; $10 \mu \mathrm{g} / \mathrm{mL}$ ) or vehicle (Dimethyl sulfoxide (DMSO); $0.1 \%$ ) for $1 \mathrm{~h}$ prior to $50 \mathrm{ng} / \mathrm{mL}$ of rmC5a treatment. After $48 \mathrm{~h}$, cytosolic protein was purified for (A) cytochrome $\mathrm{c}$ and (B) caspase 3/9 activities by ELISA. The data are represented as mean \pm SD. ${ }^{*} p<0.05$.

\subsection{High-Dose C5a Treatment Induced Oxidative Stress via NOXs-Dependent ROS Generation in Mouse KECs}

The time sequence of ROS formation in rmC5a-treated mouse KECs is shown in Figure 4A. Based on the ROS formation curve, florescence images of vehicle or $50 \mathrm{ng} / \mathrm{mL}$ of rmC5a-treated groups at 45 min revealed ROS formation (Figure 4B). To clarify the role of NADPH oxidases (NOXs) in C5a-mediated ROS formation in KECs, pan NOXs inhibitor VAS2879 was used prior to C5a treatment in KECs. The results revealed VAS2879 significantly reduced C5a enhanced ROS generation in KECs (Figure 4C), which demonstrated that C5a triggered oxidative stress via NOXs-dependent ROS generation.

\subsection{C5aR Inhibitors (W-54011) or NAC Rescued High-Dose C5a Treatment Induced ROS Formation and Apoptosis in Mouse KECs}

To evaluate the role of C5aR in C5a-induced ROS formation, mouse KECs were pretreated with the C5aR inhibitor (W-54011) or N-acetylcysteine (NAC) prior to C5a treatment. A high dose of C5a induced ROS formation, and this effect was significantly inhibited by W-54011 or NAC (Figure 5A). Furthermore, the inhibition of $\mathrm{C} 5 \mathrm{a}$, which can induce ROS formation through the C5aR inhibitors (W-54011) or NAC, also reduced cytochrome c release (Figure 5B), apoptotic cell formation (Figure 5C), and attenuated apoptotic DNA fragmentation (Figure 5D). Taken together, these results indicated that a high dose of $\mathrm{C} 5$ a may damage mouse $\mathrm{KECs}$ through $\mathrm{C} 5 \mathrm{aR} / \mathrm{ROS} /$ mitochondria-dependent apoptosis. 


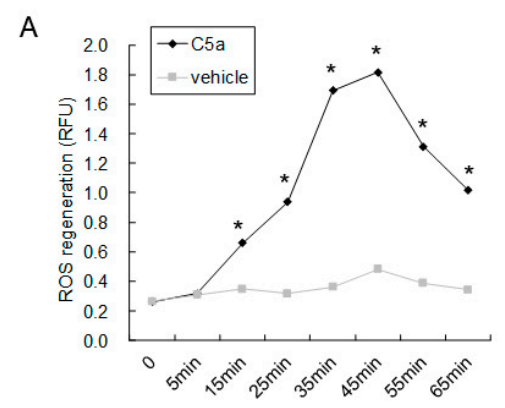

B

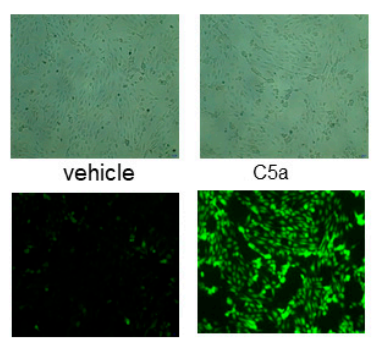

C

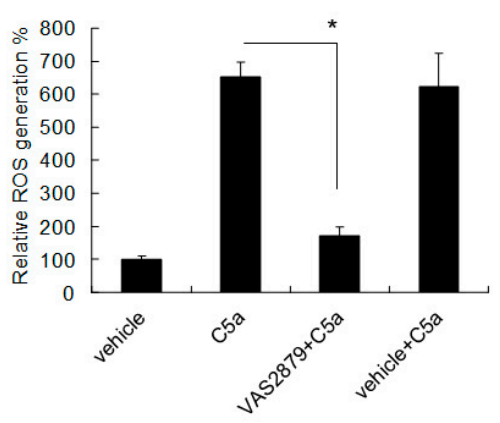

Figure 4. High-dose C5a treatment induced oxidative stress via NOXs-dependent reactive oxygen (ROS) generation in mouse KECs. (A) Mouse KECs were treated with vehicle or $50 \mathrm{ng} / \mathrm{mL}$ of rmC5a. The time sequence of ROS formation was detected by DCF-DA (Cellular Reactive Oxygen Species Detection Assay). (B) Representative florescence images of vehicle or $50 \mathrm{ng} / \mathrm{mL}$ of rmC5a-treated groups at $45 \mathrm{~min}$ were taken. (C) Mouse KECs were pretreated with pan NOXs inhibitor VAS2879 $(10 \mu \mathrm{M})$ or vehicle $(0.1 \%$ DMSO) for $30 \mathrm{~min}$ prior to $50 \mathrm{ng} / \mathrm{mL}$ of rmC5a treatment. After $45 \mathrm{~min}$, ROS formation was determined by DCF-DA. The data are represented as mean \pm SD. ${ }^{*} p<0.05$.

A

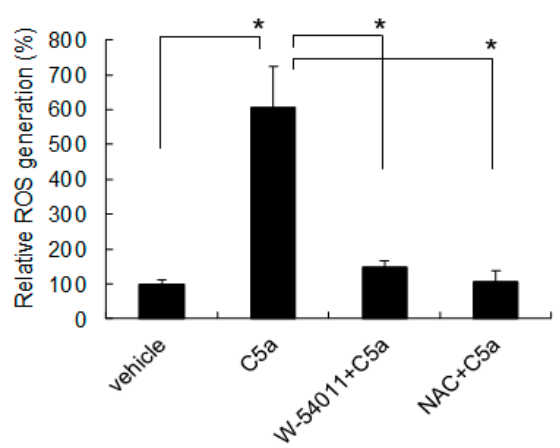

C

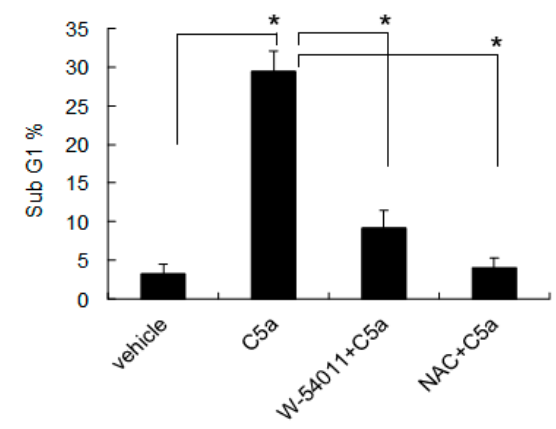

B
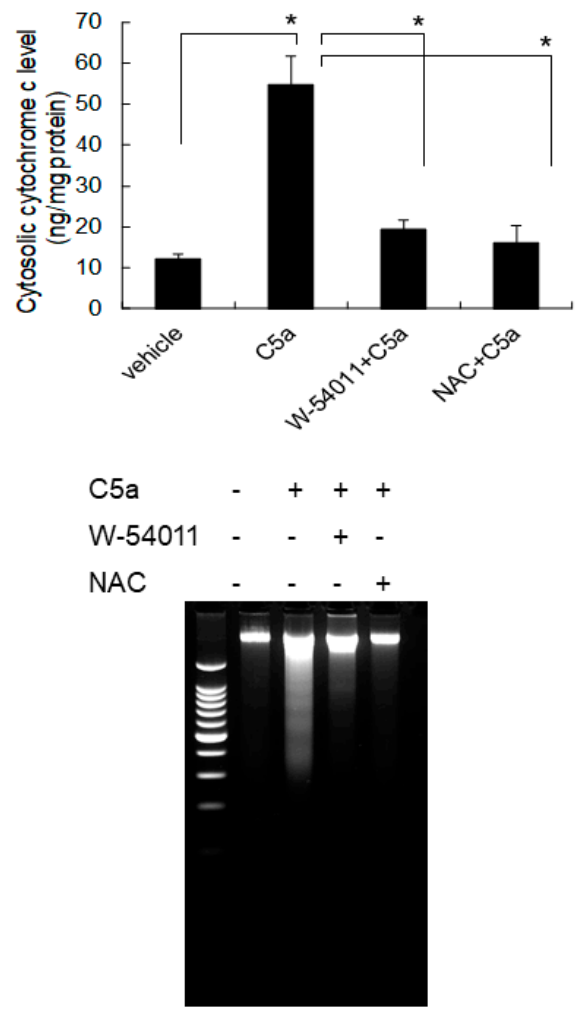

Figure 5. C5aR inhibitors (W-54011) or N-acetylcysteine (NAC) rescued high-dose C5a treatment-induced ROS formation and apoptosis in mouse KECs. (A) Mouse KECs were pretreated with the C5aR inhibitors $(\mathrm{W}-54011 ; 10 \mu \mathrm{g} / \mathrm{mL})$ or NAC $(1 \mathrm{mM})$ for $1 \mathrm{~h}$ prior to $50 \mathrm{ng} / \mathrm{mL}$ of rmC5a treatment. After $45 \mathrm{~min}$, ROS formation was detected by DCF-DA assay. (B) Mouse KECs were pretreated with the C5aR inhibitors $(\mathrm{W}-54011 ; 10 \mu \mathrm{g} / \mathrm{mL})$ or NAC $(1 \mathrm{mM})$ for $1 \mathrm{~h}$ prior to $50 \mathrm{ng} / \mathrm{mL}$ of rmC5a treatment. After $48 \mathrm{~h}$, cytosolic protein was purified to determine cytochrome c content using ELISA. (C) Mouse KECs were pretreated with the C5aR inhibitor (W-54011; $10 \mu \mathrm{g} / \mathrm{mL}$ ) or NAC $(1 \mathrm{mM})$ for $1 \mathrm{~h}$ prior to $50 \mathrm{ng} / \mathrm{mL}$ of rmC5a treatment. After $48 \mathrm{~h}$, the apoptotic phase (subG1 phase) was analyzed by propidium iodide staining and flow cytometry. (D) Using the same treatment groups as described in (C), after $48 \mathrm{~h}$, the total DNA of each group was purified to determine apoptotic DNA fragmentation using gel electrophoresis. The data are presented as mean $\pm \mathrm{SD}$. ${ }^{*} p<0.05$. 


\section{Discussion}

C5a is cleaved from complement component C5 by C5-convertase in the complement cascade, and it is an active peptide in anaphylactic reactions and inflammatory processes. C5a stimulates mast cell degranulation, stimulates the release of tumor necrosis factor- $\alpha$ (TNF- $\alpha$ ) and histamine, and recruits phagocytes to sites of infection and inflammation by increasing adhesion molecule expression on the surface of endothelial cells [21,22]. C5a also increases vascular permeability in some pathological stimuli, such as allograft rejection after transplantation and asthma $[4,23,24]$ The serum level of C5a has been discussed in several studies. In a study by Lechner et al., the C5a level was $8.34+2.05(\mathrm{ng} / \mathrm{mL}) \mathrm{in}$ the control group [25]. Under normal conditions, the plasma C5a level is quite low [26,27] because of the rapid clearance of anaphylatoxin [28]. In our previous study, the nephrotic syndrome patients with relapse showed a higher serum C5a level $(44.30+32.95 \mathrm{ng} / \mathrm{mL})$ compared to remission status $(22.31+$ $14.62 \mathrm{ng} / \mathrm{mL}$ ) [11]. In murine cortical tubular cells, after treatment with C5a (25 nM), transforming growth factor- $\beta$ (TGF- $\beta$ ) was elevated which has been shown to lead to renal fibrosis and renal scar formation [29].

In the GFB, the key mechanism regulating the barrier between podocytes and glomerular endothelial cells is still under debate. Due to the presence of large fenestrations of glomerular endothelial cells, the endothelium has not traditionally been considered to be a major contributor to GFB function, and massive proteinuria has been noted when certain proteins on podocytes are defective or absent, such as in congenital nephrotic syndrome [30,31]. However, the role of glomerular endothelial cells has recently been reconsidered. In a diabetic mice model, endothelial nitric oxide synthetase deficiency was shown to cause heavy proteinuria and structural changes of podocytes in a similar manner to podocyte changes in minimal change disease [32]. In a study of the effect of angiopoietin-2 on podocytes, the overexpression of angiopoietin-2 induced the apoptosis of glomerular endothelial cells and the presence of albuminuria; however, the structure of podocytes remained intact [33].

C5a is a potent proinflammatory molecule [34] which binds to C5aR (CD88), a classical G protein-coupled receptor (GPCR), and elicits the signaling pathways of proinflammatory responses [35]. $\mathrm{C} 5 \mathrm{aR}$ is expressed in different non-myeloid cells, such as human umbilical vascular endothelial cells (HUVEC), murine dermal, liver, pulmonary and renal proximal tubules [20,36-39]. We previously demonstrated that $\mathrm{C} 5 \mathrm{aR}$ was expressed in glomerular endothelial cells but not in podocytes, indicating that C5a may cause proteinuria on the primary target of renal endothelial cells [11].

Previous studies have shown that C5a may induce lymphocyte apoptosis which presents as immunosuppression in severe sepsis, and in some critical conditions, the loss of regulation of C5a may cause plasma concentrations in excess of $100 \mathrm{nmol} / \mathrm{L}[13,27,40]$. In sepsis, high concentrations of proinflammatory mediators, such as $\mathrm{C} 5 \mathrm{a}$, may be associated with apoptotic cell death. In a HUVEC study, C5a enhanced the gene expressions of chemokines (interleukin-1/interleukin-6), cell adherence molecules (intercellular adhesion molecule-1 (ICAM-1)/vascular cell adhesion protein 1 (VCAM-1)/E-selectin), growth factors VEGF/platelet-derived growth factor (PDGF)), and pro-apoptotic molecules (caspase 3, caspase 8, cellular FLICE inhibitory protein (cFLIP)) [41]. In addition, C5a has been shown to affect ROS production in neutrophils, and C5a-induced apoptosis has been shown to be dependent on phosphoinositide signaling [42,43], which then reduces endothelial integrity [44]. In recent studies of lupus, $\mathrm{C} 5 \mathrm{a} / \mathrm{C} 5 \mathrm{aR} 1$ signaling was shown to induce the apoptosis of brain endothelial cells, and this effect was inhibited by C5a/C5aR1 antagonists $[45,46]$. Furthermore, in a study by Drummond et al., it was shown that NOXs are possible mediators in C5a-triggering oxidative stress [47].

Apoptosis is a procedure of active cell death-an energy-requiring process-which regulates the number of cells $[48,49]$. In addition, apoptosis also regulates immune and inflammatory cells, the number of fibroblasts, and vascular homeostasis [50]. In regard to kidney cells, the apoptosis of renal parenchymal cells is related to cell damage, which causes a decrease in the number of kidney epithelial cells [51-53], leading to acute or chronic kidney injury. During apoptosis, the mitochondria is the most important factor in the intrinsic pathway, which produces pre-apoptotic factors, including cytochrome 
c, apoptosis-inducing factor (AIF) and Smac/DIABLO [54,55], causing proteolysis and cell death. In kidney cells, cascade-dependent apoptosis and cell death can be caused by nephrotoxic agents in glomerular and tubular epithelium through mitochondrial injury and caspase cascade activation [50]. For example, in cyclosporin A-induced nephrotoxicity, Bax aggregation and translocation to the mitochondria in renal tubular cells may change the permeability of outer mitochondrial membranes to release cytochrome $c$ and Smac/DIABLO and then activate caspase 3/9, which causes cell apoptosis and death [56]. However, the apoptosis pathways in KECs are still unclear.

Our results demonstrated the significant apoptosis of mouse KECs treated with high concentrations of rmC5a, which decreased cell viability and increased the sub-G1 phase in cell cycle phase analysis. In addition, our data also showed that rmC5a signaling was done through C5aR on mouse KECs, and that this induced cytochrome $\mathrm{c}$ and caspase $3 / 9$ activities which were dependent on ROS regeneration; therefore, this was mitochondrial-dependent apoptosis. In advance, C5a-triggered oxidative stress may be through NOXs-dependent ROS generation. Of note, this study is the first to show that a high dose of C5a may damage mouse KECs through C5aR, thereby causing mitochondrial-dependent apoptosis. This is in line with the beneficial effects of the $\mathrm{C} 5 \mathrm{a} / \mathrm{C} 5 \mathrm{a}$ receptor blockade in treating experimental sepsis. Our findings not only shed light on the potential mechanism of glomerular sclerosis in idiopathic nephrotic syndrome, a process of renal impairment, but also a possible direction for novel therapeutic approaches in complement-mediated KEC apoptosis.

\section{Materials and Methods}

\subsection{Mouse Kidney Endothelial Cell (KEC) Preparation}

The kidney glomeruli of 20 mice aged between 6 and 8 weeks were isolated and minced in sterile conditions by stepwise sieving with stainless steel sieves of different pole sizes $(150,90,75$, 53 , and $32 \mu \mathrm{m}$ ). The isolated glomeruli were then washed in $50 \mathrm{~mL}$ of Dulbecco's modified Eagle's medium (DMEM) (Invitrogen) followed by a treatment at $37^{\circ} \mathrm{C}$ for $1.5 \mathrm{~h}$ with $2.5 \mathrm{~mL}$ of $0.1 \%$ type II collagenase in DMEM. Five $\mathrm{ml}$ of Hanks' balanced salt solution containing $10 \%$ fetal calf serum (Invitrogen) was then used to wash the cell suspension. The endothelial cells from mouse kidney tissue were isolated by immunomagnetic purification with anti-CD31-coated Dynabeads ${ }^{\circledR}$. The isolated endothelial cells were resuspended in $1 \mathrm{~mL}$ of a cold M199 medium containing $0.3 \mathrm{mg} / \mathrm{mL}$ of magnetic tosyl-activated M450 Dynabeads with mouse anti-mouse CD31, and they were then incubated at room temperature for $30 \mathrm{~min}$ with gentle agitation. An MPC-1 magnet (Dynal, Oslo, Norway) was used to isolate endothelial cells bound to the magnetic beads from the unbound non-endothelial cells. The magnetic bead-bound cells were resuspended and cultured in an endothelial cell growth medium (Cell Applications, San Diego, CA, USA). The ratio of CD31-positive cells was analyzed by quantifying the CD31-positive cells (stained by PECAM-1 which also referred to as CD31 Antibody; sc-376764 FITC) by flow cytometry using a FACS scan and the Cell Quest software (Becton Dickinson Immunocytometry Systems, San Jose, CA, USA). All animal experiments were performed according to the protocols approved by the Institutional Animal Care and Use Committee (IACUC) of National Taiwan University College of Medicine (No. 20160138), and the care and use of the animals was in accordance with the guidelines of National Institutes of Health (NIH).

\subsection{Recombinant Protein and Chemical Reagents}

Mouse recombinant protein C5a (rmC5a) was purchased from R\&D Systems. The C5aR inhibitor W-54011, VAS2870, DMSO, DCF-DA and NAC were purchased from Sigma-Aldrich (St. Louis, MO, USA).

\subsection{Cell Viability Determination}

Cells were cultured in 96-well plates at $2 \times 1000$ cells/well with individual experimental conditions. The growth inhibitory effects were measured. At the indicated time periods, we added $30 \mu \mathrm{L}$ of a 
$5 \mathrm{mg} / \mathrm{mL}$ MTT solution (Sigma-Aldrich, St. Louis, MO, USA) to each well and then incubated the cells at $37^{\circ} \mathrm{C}$ for $4 \mathrm{~h}$. The cell culture supernatant was then aspirated. The developed formazan crystals were then dissolved in $200 \mu \mathrm{L}$ of DMSO (Sigma-Aldrich, St. Louis, MO, USA) for $10 \mathrm{~min}$, and an ELISA reader at $540 \mathrm{~nm}$ was used to analyze the absorbance. The percentage of viability in control cells was presented as absorbance values. All values were presented as mean \pm standard deviation (SD) of at least three independent experiments.

\subsection{Cell Cycle and Apoptosis Analysis Determined by Flow Cytometry}

Cells were cultured in a six-well plate $(50,000$ cells/well) and incubated overnight. After experimental treatment, the attached cells were collected and fixed with methanol at $-20{ }^{\circ} \mathrm{C}$ for at least $30 \mathrm{~min}$ and then stained with $10 \mathrm{mg} / \mathrm{mL}$ of propidium iodide and $100 \mathrm{mg} / \mathrm{mL}$ of RNase A for $30 \mathrm{~min}$ in the dark. Flow cytometric analysis (FACSCalibur; Becton Dickinson, San Jose, CA, USA and Cell Quest software (Becton Dickinson) were used to determine cell cycle distribution. For apoptosis analysis, KECs were resuspended in $100 \mu \mathrm{L}$ of an Annexin V (AV) binding buffer (10 mM HEPES (pH 7.4), $140 \mathrm{mM} \mathrm{NaCl}$, and $2.5 \mathrm{mM} \mathrm{CaCl}_{2}$ ) and then added to fluorescein isothiocyanate-conjugated $\mathrm{AV}$ ( $5 \mu \mathrm{L}$; Invitrogen Corporation, Carlsbad, CA, USA) and PI $(1 \mu \mathrm{L}, 1 \mathrm{mg} / \mathrm{mL}$; Invitrogen, Carlsbad, CA, USA). After incubation for $20 \mathrm{~min}, 400 \mathrm{uL}$ of the annexin $\mathrm{V}$ binding buffer was added, and the cells were analyzed by flow cytometry as described above. All values were presented as mean + standard deviation (SD) of at least three independent experiments.

\subsection{Lactate Dehydrogenase (LDH) Assay}

The cell culture supernatant of KECs was processed for measuring LDH activities by using an Abcam's LDH assay kit (Colorimetric: ab102526) according to the manufacturer's protocols. $50 \mu \mathrm{L}$ of culture supernatant from each sample was collected and combined with $50 \mu \mathrm{L}$ of Reaction Mix (contain the LDH Assay Buffer and the LDH Substrate Mix) at $37^{\circ} \mathrm{C}$ protected from light. After $30 \mathrm{~min}$, the LDH activity was measured at $450 \mathrm{~nm}$ using a microplate reader (Bio-Rad Laboratories, Hercules, CA, USA).

\subsection{Cytochrome c Release and Caspase 3/9 Activity Determination}

Cells were cultured in a six-well plate (50,000 cells/well) and incubated overnight. After experimental treatment, cytosolic protein was purified to determine cytochrome c and caspase 3/9 activities using a Rat/Mouse Cytochrome c Quantikine ELISA Kit (R\&D Systems, Minneapolis, MN, USA), Caspase-3/CPP32 Colorimetric Assay Kit (R\&D Systems) and Caspase-9 Colorimetric Assay Kit (R\&D Systems), respectively, according to the manufacturer's instructions. The cytosolic proteins of KECs were isolated by Abcam's Cell Fractionation Kit (Standard Cell Fractionation Kit - Standard; ab109719). KECs cells were suspended in buffer $A$, and then the cell suspension was diluted with an equal volume of buffer $B$ in $1.5 \mathrm{~mL}$ microcentrifuge tubes containing protease inhibitors, and the tube was incubated with constant mixing for $7 \mathrm{~min}$ on a rotator at room temperature. Then, samples were centrifuged at $5000 \times g$ for $1 \mathrm{~min}$ at $4{ }^{\circ} \mathrm{C}$. All supernatants were carefully removed and transferred to a new set of tubes. The supernatant fractions were re-centrifuged at $10,000 \times g$ for $1 \mathrm{~min}$. Again, all of the supernatants were carefully removed and transferred to a new set of tubes. The concentration of cytosolic proteins was quantified using a Bio-Rad protein assay reagent (Bio-Rad Laboratories, Hercules, CA, USA).

\subsection{ROS Formation Determination by DCF-DA}

Changes in the ROS content in cells were determined using the fluorescent dye DCF-DA. KECs were placed in a six-well plate $(50,000$ cells/well $) 48 \mathrm{~h}$ before the experiment. The cells were then cultured in a serum-free medium for $6 \mathrm{~h}$ followed by incubation with $10 \mu \mathrm{mol} / \mathrm{L}$ of DCF-DA (Sigma, Saint Louis, MO, USA) for 30 min. DCF-DA fluorescent emission was measured using a Beckman Coulter DTX 880 Multimode Detector at $530 \mathrm{~nm}$, with excitation at a wavelength of $488 \mathrm{~nm}$. 


\subsection{Visualization of DNA Fragmentation with Gel Electrophoresis}

DNA was extracted from cells by the phenol-chloroform method. Electrophoresis was performed on $2 \%$ agarose gels in a Tris/acetate acid/EDTA buffer. The gels were stained with ethidium bromide to show the DNA fragments and photographed with a digital camera.

\subsection{Statistical Analysis}

All data were expressed as mean $\pm \mathrm{SD}$. In cell studies, a two-tailed $t$-test was used to evaluate statistically significant differences between two groups. A $p$ value $<0.05$ was considered to indicate a statistically significant difference.

Author Contributions: I.-J.T. and C.-H.C. designed and conceived the research; I.-J.T., Y.-L.T. and C.-H.C. performed the experiments; I.-J.T., W.-C.L., Y.-H.Y., Y.-H.L. and C.-H.C. analyzed the data; I.-J.T. and C.-H.C. interpreted results of experiments; C.-H.C. prepared figures; I.-J.T., Y.-H.L. and C.-H.C. drafted the manuscript; I.-J.T., C.-H.C. and Y.-K.T. edited the manuscript; I.-J.T., W.-C.L., Y.-H.Y., Y.-L.T., Y.-H.L., C.-H.C. and Y.-K.T. approved the final version of manuscript.

Funding: This study is supported by National Taiwan University Hospital grants (NTUH 106-s3479, 107-s3959, and 108-s4243) and the Ministry of Science and Technology (MOST 107-2635-B-002-003, and 108-2314-B-002-067-MY2) to I.-J.T.

Conflicts of Interest: The authors declare no conflict of interest.

\section{References}

1. Schulman, E.S.; Post, T.J.; Henson, P.M.; Giclas, P.C. Differential effects of the complement peptides, C5a and C5a des Arg on human basophil and lung mast cell histamine release. J. Clin. Investig. 1988, 81, 918-923. [CrossRef] [PubMed]

2. Becker, E.L. The relationship of the chemotactic behavior of the complement-derived factors, C3a, C5a, and $\mathrm{C} 567$, and a bacterial chemotactic factor to their ability to activate the proesterase 1 of rabbit polymorphonuclear leukocytes. J. Exp. Med. 1972, 135, 376-387. [CrossRef] [PubMed]

3. Wenderfer, S.E.; Ke, B.; Hollmann, T.J.; Wetsel, R.A.; Lan, H.Y.; Braun, M.C. C5a receptor deficiency attenuates $\mathrm{T}$ cell function and renal disease in MRLlpr mice. J. Am. Soc. Nephrol. 2005, 16, 3572-3582. [CrossRef] [PubMed]

4. Gueler, F.; Rong, S.; Gwinner, W.; Mengel, M.; Bröcker, V.; Schön, S.; Greten, T.F.; Hawlisch, H.; Polakowski, T.; Schnatbaum, K.; et al. Complement 5a receptor inhibition improves renal allograft survival. J. Am. Soc. Nephrol. 2008, 19, 2302-2312. [CrossRef] [PubMed]

5. Arumugam, T.V.; Shiels, I.A.; Strachan, A.J.; Abbenante, G.; Fairlie, D.P.; Taylor, S.M. A small molecule C5a receptor antagonist protects kidneys from ischemia/reperfusion injury in rats. Kidney Int. 2003, 63, $134-142$. [CrossRef] [PubMed]

6. De Vries, B.; Kohl, J.; Leclercq, W.K.; Wolfs, T.G.; van Bijnen, A.A.; Heeringa, P.; Buurman, W.A. Complement factor C5a mediates renal ischemia-reperfusion injury independent from neutrophils. J. Immunol. 2003, 170, 3883-3889. [CrossRef] [PubMed]

7. Branten, A.J.; van den Born, J.; Jansen, J.L.; Assmann, K.J.; Wetzels, J.F. Familial nephropathy differing from minimal change nephropathy and focal glomerulosclerosis. Kidney Int. 2001, 59, 693-701. [CrossRef] [PubMed]

8. Pagtalunan, M.E.; Miller, P.L.; Jumping-Eagle, S.; Nelson, R.G.; Myers, B.D.; Rennke, H.G.; Coplon, N.S.; Sun, L.; Meyer, T.W. Podocyte loss and progressive glomerular injury in type II diabetes. J. Clin. Investig. 1997, 99, 342-348. [CrossRef] [PubMed]

9. Stillman, I.E.; Karumanchi, S.A. The glomerular injury of preeclampsia. J. Am. Soc. Nephrol. 2007, 18, 2281-2284. [CrossRef] [PubMed]

10. Eremina, V.; Sood, M.; Haigh, J.; Nagy, A.; Lajoie, G.; Ferrara, N.; Gerber, H.P.; Kikkawa, Y.; Miner, J.H.; Quaggin, S.E. Glomerular-specific alterations of VEGF-A expression lead to distinct congenital and acquired renal diseases. J. Clin. Investig. 2003, 111, 707-716. [CrossRef] [PubMed] 
11. Tsai, I.J.; Chou, C.H.; Yang, Y.H.; Lin, W.C.; Lin, Y.H.; Chow, L.P.; Lee, H.H.; Kao, P.G.; Liau, W.T.; Jou, T.S.; et al. Inhibition of Rho-associated kinase relieves C5a-induced proteinuria in murine nephrotic syndrome. Cell. Mol. Life Sci. 2015, 72, 3157-3171. [CrossRef] [PubMed]

12. Back, M. Inflammatory signaling through leukotriene receptors in atherosclerosis. Curr. Atheroscler. Rep. 2008, 10, 244-251. [CrossRef] [PubMed]

13. Riedemann, N.C.; Guo, R.F.; Neff, T.A.; Laudes, I.J.; Keller, K.A.; Sarma, V.J.; Markiewski, M.M.; Mastellos, D.; Strey, C.W.; Pierson, C.L.; et al. Increased C5a receptor expression in sepsis. J. Clin. Investig. 2002, 110, 101-108. [CrossRef] [PubMed]

14. Srinivasan, S.R.; Radhakrishnamurthy, B.; Vijayagopal, P.; Berenson, G.S. Proteoglycans, lipoproteins, and atherosclerosis. Adv. Exp. Med. Biol. 1991, 285, 373-381. [PubMed]

15. Wesche, D.E.; Lomas-Neira, J.L.; Perl, M.; Chung, C.S.; Ayala, A. Leukocyte apoptosis and its significance in sepsis and shock. J. Leukoc. Biol. 2005, 78, 325-337. [CrossRef] [PubMed]

16. Li, Q.; Peng, Q.; Xing, G.; Li, K.; Wang, N.; Farrar, C.A.; Meader, L.; Sacks, S.H.; Zhou, W. Deficiency of C5aR prolongs renal allograft survival. J. Am. Soc. Nephrol. 2010, 21, 1344-1353. [CrossRef] [PubMed]

17. Foreman, K.E.; Vaporciyan, A.A.; Bonish, B.K.; Jones, M.L.; Johnson, K.J.; Glovsky, M.M.; Eddy, S.M.; Ward, P.A. C5a-induced expression of P-selectin in endothelial cells. J. Clin. Investig. 1994, 94, 1147-1155. [CrossRef] [PubMed]

18. Gasque, P.; Singhrao, S.K.; Neal, J.W.; Gotze, O.; Morgan, B.P. Expression of the receptor for complement C5a (CD88) is up-regulated on reactive astrocytes, microglia, and endothelial cells in the inflamed human central nervous system. Am. J. Pathol. 1997, 150, 31-41. [PubMed]

19. Guo, R.F.; Sun, L.; Gao, H.; Shi, K.X.; Rittirsch, D.; Sarma, V.J.; Zetoune, F.S.; Ward, P.A. In vivo regulation of neutrophil apoptosis by C5a during sepsis. J. Leukoc. Biol. 2006, 80, 1575-1583. [CrossRef] [PubMed]

20. Monsinjon, T.; Gasque, P.; Chan, P.; Ischenko, A.; Brady, J.J.; Fontaine, M.C. Regulation by complement C3a and C5a anaphylatoxins of cytokine production in human umbilical vein endothelial cells. FASEB J. 2003, 17, 1003-1014. [CrossRef]

21. Mollnes, T.E.; Brekke, O.L.; Fung, M.; Fure, H.; Christiansen, D.; Bergseth, G.; Videm, V.; Lappegard, K.T.; Kohl, J.; Lambris, J.D. Essential role of the C5a receptor in E coli-induced oxidative burst and phagocytosis revealed by a novel lepirudin-based human whole blood model of inflammation. Blood 2002, 100, 1869-1877. [PubMed]

22. Riedemann, N.C.; Guo, R.F.; Bernacki, K.D.; Reuben, J.S.; Laudes, I.J.; Neff, T.A.; Gao, H.; Speyer, C.; Sarma, V.J.; Zetoune, F.S.; et al. Regulation by C5a of neutrophil activation during sepsis. Immunity 2003, 19, 193-202. [CrossRef]

23. Krug, N.; Tschernig, T.; Erpenbeck, V.J.; Hohlfeld, J.M.; Kohl, J. Complement factors C3a and C5a are increased in bronchoalveolar lavage fluid after segmental allergen provocation in subjects with asthma. Am. J. Respir. Crit. Care Med. 2001, 164, 1841-1843. [CrossRef] [PubMed]

24. Khan, M.A.; Maasch, C.; Vater, A.; Klussmann, S.; Morser, J.; Leung, L.L.; Atkinson, C.; Tomlinson, S.; Heeger, P.S.; Nicolls, M.R. Targeting complement component 5a promotes vascular integrity and limits airway remodeling. Proc. Natl. Acad. Sci. USA 2013, 110, 6061-6066. [CrossRef] [PubMed]

25. Lechner, J.; Chen, M.; Hogg, R.E.; Toth, L.; Silvestri, G.; Chakravarthy, U.; Xu, H. Higher plasma levels of complement C3a, C4a and C5a increase the risk of subretinal fibrosis in neovascular age-related macular degeneration: Complement activation in AMD. Immun. Ageing 2016, 13, 4. [CrossRef] [PubMed]

26. Solomkin, J.S.; Jenkins, M.K.; Nelson, R.D.; Chenoweth, D.; Simmons, R.L. Neutrophil dysfunction in sepsis. II. Evidence for the role of complement activation products in cellular deactivation. Surgery 1981, 90, 319-327.

27. Wood, A.J.T.; Vassallo, A.; Summers, C.; Chilvers, E.R.; Conway-Morris, A. C5a anaphylatoxin and its role in critical illness-induced organ dysfunction. Eur. J. Clin. Investig. 2018, 48, e13028. [CrossRef] [PubMed]

28. Oppermann, M.; Gotze, O. Plasma clearance of the human C5a anaphylatoxin by binding to leucocyte C5a receptors. Immunology 1994, 82, 516-521. [PubMed]

29. Boor, P.; Konieczny, A.; Villa, L.; Schult, A.-L.; Bücher, E.; Rong, S.; Kunter, U.; van Roeyen, C.R.C.; Polakowski, T.; Hawlisch, H.; et al. Complement C5 Mediates Experimental Tubulointerstitial Fibrosis. J. Am. Soc. Nephrol. 2007, 18, 1508-1515. [CrossRef] [PubMed]

30. Kestilä, M.; Lenkkeri, U.; Männikkö, M.; Lamerdin, J.; McCready, P.; Putaala, H.; Ruotsalainen, V.; Morita, T.; Nissinen, M.; Herva, R.; et al. Positionally cloned gene for a novel glomerular protein—nephrin—is mutated in congenital nephrotic syndrome. Mol. Cell. 1998, 1, 575-582. [CrossRef] 
31. Tryggvason, K.; Patrakka, J.; Wartiovaara, J. Hereditary proteinuria syndromes and mechanisms of proteinuria. N. Engl. J. Med. 2006, 354, 1387-1401. [CrossRef] [PubMed]

32. Yuen, D.A.; Stead, B.E.; Zhang, Y.; White, K.E.; Kabir, M.G.; Thai, K.; Advani, S.L.; Connelly, K.A.; Takano, T.; Zhu, L.; et al. eNOS deficiency predisposes podocytes to injury in diabetes. J. Am. Soc. Nephrol. 2012, 23, 1810-1823. [CrossRef] [PubMed]

33. Davis, B.; Dei Cas, A.; Long, D.A.; White, K.E.; Hayward, A.; Ku, C.H.; Woolf, A.S.; Bilous, R.; Viberti, G.; Gnudi, L. Podocyte-specific expression of angiopoietin-2 causes proteinuria and apoptosis of glomerular endothelia. J. Am. Soc. Nephrol. 2007, 18, 2320-2329. [CrossRef] [PubMed]

34. Klos, A.; Tenner, A.J.; Johswich, K.O.; Ager, R.R.; Reis, E.S.; Kohl, J. The role of the anaphylatoxins in health and disease. Mol. Immunol. 2009, 46, 2753-2766. [CrossRef] [PubMed]

35. Li, R.; Coulthard, L.G.; Wu, M.C.; Taylor, S.M.; Woodruff, T.M. C5L2: A controversial receptor of complement anaphylatoxin, C5a. FASEB J. 2013, 27, 855-864. [CrossRef] [PubMed]

36. Gerard, C.; Gerard, N.P. C5A anaphylatoxin and its seven transmembrane-segment receptor. Annu. Rev. Immunol. 1994, 12, 775-808. [CrossRef]

37. Haviland, D.L.; McCoy, R.L.; Whitehead, W.T.; Akama, H.; Molmenti, E.P.; Brown, A.; Haviland, J.C.; Parks, W.C.; Perlmutter, D.H.; Wetsel, R.A. Cellular expression of the C5a anaphylatoxin receptor (C5aR): Demonstration of C5aR on nonmyeloid cells of the liver and lung. J. Immunol. 1995, 154, 1861-1869.

38. Fayyazi, A.; Scheel, O.; Werfel, T.; Schweyer, S.; Oppermann, M.; Gotze, O.; Radzun, H.J.; Zwirner, J. The C5a receptor is expressed in normal renal proximal tubular but not in normal pulmonary or hepatic epithelial cells. Immunology 2000, 99, 38-45. [CrossRef]

39. Schraufstatter, I.U.; Trieu, K.; Sikora, L.; Sriramarao, P.; DiScipio, R. Complement c3a and c5a induce different signal transduction cascades in endothelial cells. J. Immunol. 2002, 169, 2102-2110. [CrossRef]

40. Ward, P.A. The dark side of C5a in sepsis. Nat. Rev. Immunol. 2004, 4, 133-142. [CrossRef]

41. Albrecht, E.A.; Chinnaiyan, A.M.; Varambally, S.; Kumar-Sinha, C.; Barrette, T.R.; Sarma, J.V.; Ward, P.A. C5a-induced gene expression in human umbilical vein endothelial cells. Am. J. Pathol. 2004, 164, 849-859. [CrossRef]

42. Perianayagam, M.C.; Balakrishnan, V.S.; King, A.J.; Pereira, B.J.; Jaber, B.L. C5a delays apoptosis of human neutrophils by a phosphatidylinositol 3-kinase-signaling pathway. Kidney Int. 2002, 61, 456-463. [CrossRef] [PubMed]

43. Perianayagam, M.C.; Balakrishnan, V.S.; Pereira, B.J.; Jaber, B.L. C5a delays apoptosis of human neutrophils via an extracellular signal-regulated kinase and Bad-mediated signalling pathway. Eur. J. Clin. Investig. 2004, 34, 50-56. [CrossRef] [PubMed]

44. Mahajan, S.D.; Parikh, N.U.; Woodruff, T.M.; Jarvis, J.N.; Lopez, M.; Hennon, T.; Cunningham, P.; Quigg, R.J.; Schwartz, S.A.; Alexander, J.J. C5a alters blood-brain barrier integrity in a human in vitro model of systemic lupus erythematosus. Immunology 2015, 146, 130-143. [CrossRef] [PubMed]

45. Jacob, A.; Hack, B.; Bai, T.; Brorson, J.R.; Quigg, R.J.; Alexander, J.J. Inhibition of C5a receptor alleviates experimental CNS lupus. J. Neuroimmunol. 2010, 221, 46-52. [CrossRef] [PubMed]

46. Mahajan, S.D.; Tutino, V.M.; Redae, Y.; Meng, H.; Siddiqui, A.; Woodruff, T.M.; Jarvis, J.N.; Hennon, T.; Schwartz, S.; Quigg, R.J.; et al. C5a induces caspase-dependent apoptosis in brain vascular endothelial cells in experimental lupus. Immunology 2016, 148, 407-419. [CrossRef] [PubMed]

47. Drummond, G.R.; Sobey, C.G. Endothelial NADPH oxidases: Which NOX to target in vascular disease? Trends Endocrinol. Metab. 2014, 25, 452-463. [CrossRef] [PubMed]

48. Green, D.R.; Kroemer, G. Pharmacological manipulation of cell death: Clinical applications in sight? J. Clin. Investig. 2005, 115, 2610-2617. [CrossRef]

49. Riedl, S.J.; Salvesen, G.S. The apoptosome: Signalling platform of cell death. Nat. Rev. Mol. Cell Biol. 2007, 8, 405-413. [CrossRef]

50. Sanz, A.B.; Santamaría, B.; Ruiz-Ortega, M.; Egido, J.; Ortiz, A. Mechanisms of renal apoptosis in health and disease. J. Am. Soc. Nephrol. 2008, 19, 1634-1642. [CrossRef]

51. Olsen, T.S.; Olsen, H.S.; Hansen, H.E. Tubular ultrastructure in acute renal failure in man: Epithelial necrosis and regeneration. Vichows Arch. A Pathol. Anat. 1985, 406, 75-89. [CrossRef]

52. Shankland, S.J. The podocyte's response to injury: Role in proteinuria and glomerulosclerosis. Kidney Int. 2006, 69, 2131-2147. [CrossRef] 
53. Hughes, J.; Savill, J.S. Apoptosis in glomerulonephritis. Curr. Opin. Nephrol. Hypertens. 2005, 14, $389-395$. [CrossRef] [PubMed]

54. Ferri, K.F.; Kroemer, G. Organelle-specific initiation of cell death pathways. Nat. Cell Biol. 2001, 3, E255-E263. [CrossRef] [PubMed]

55. Ravagnan, L.; Roumier, T.; Kroemer, G. Mitochondria, the killer organelles and their weapons. J. Cell. Physiol. 2002, 192, 131-137. [CrossRef] [PubMed]

56. Justo, P.; Lorz, C.; Sanz, A.; Egido, J.; Ortiz, A. Intracellular Mechanisms of Cyclosporin A-Induced Tubular Cell Apoptosis. J. Am. Soc. Nephrol. 2003, 14, 3072-3080. [CrossRef]

(C) 2019 by the authors. Licensee MDPI, Basel, Switzerland. This article is an open access article distributed under the terms and conditions of the Creative Commons Attribution (CC BY) license (http://creativecommons.org/licenses/by/4.0/). 